\title{
MODEL PENGELOLAAN SUMBER DAYA PERIKANAN TANGKAP BERBASIS RESOLUSI KONFLIK
}

\author{
Model of Capture Fisheries Resources Management Based on Conflict Resolution \\ Oleh:

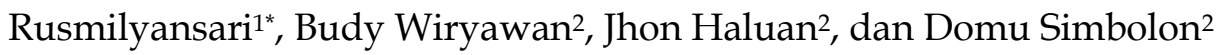 \\ ${ }^{1}$ Program Studi Pemanfaatan Sumber Daya Perikanan, Fakultas Perikanan UNLAM \\ 2 Departemen Pemanfaatan Sumber Daya Perikanan, FPIK, IPB, Jl. Lingkar Kampus, Darmaga - Bogor 16680 \\ *Korespondensi: r_melyan@yahoo.com
}

Diterima: 1 Mei 2010; Disetujui: 27 September 2010

\begin{abstract}
Capture fishery conflicts is one issue that requires serious attention. The government has tried to overcome the fisheries conflicts by issuing various regulations, but the results have not been effective. This study aims to create a model of conflict management. The research method used the perception survey. Primary data collected through using a structured questionnaire done purposively to some respondents. Analytical survey of perceptions using SEM (Structural Equation Modeling). The results showed: (i) Simultaneously, the better the ability to identify the causes of the conflict the better the ability to determine the conflict resolution techniques. Furthermore, the better the ability to determine an appropriate conflict resolution techniques will increase support for the management of fisheries resources is responsible (ii) Partially causes of conflict are determined by the indicators of competition, opposition, economic, actors and cultural (ii) facilitation techniques, negotiation, litigation and avoidance can be used as an appropriate conflict resolution techniques (iii) an understanding of community participation and conservation of fishery resources determines the creation of sustainable fisheries resource management is responsible.
\end{abstract}

Key words: capture fisheries resources, conflict resolution, management

\section{ABSTRAK}

Konflik perikanan tangkap merupakan salah satu isu yang membutuhkan perhatian serius. Pemerintah telah berupaya untuk mengatasi konflik perikanan tangkap yang muncul dengan mengeluarkan berbagai peraturan, namun hasilnya masih belum efektif. Penelitian ini bertujuan untuk membuat model pengelolaan konflik. Metode penelitian yang digunakan yaitu survei persepsi. Metode primer dikumpulkan secara purposive terhadap beberapa orang responden. Menggunakan analisis Structural Equation Modeling (SEM). Hasil penelitian menunjukkan: (i) Secara simultan, semakin baik kemampuan mengidentifikasi faktor penyebab konflik maka semakin baik kemampuan menentukan teknik resolusi konflik. Selanjutnya semakin baik kemampuan menentukan teknik resolusi konflik yang tepat maka akan meningkatkan dukungan terhadap pengelolaan sumber daya perikanan tangkap yang bertanggung jawab; (ii) Secara parsial faktor penyebab konflik ditentukan oleh indikator kompetisi, oposisi, ekonomi, aktor dan budaya; (iii) teknik fasilitasi, negosiasi, litigasi dan avoidance dapat digunakan sebagai teknik resolusi konflik yang tepat; (iv) pemahaman terhadap partisipasi masyarakat dan pelestarian sumber daya perikanan tangkap berkelanjutan menentukan terciptanya pengelolaan sumber daya perikanan tangkap yang bertanggung jawab.

Kata kunci: sumber daya perikanan tangkap, resolusi konflik, pengelolaan 


\section{PENDAHULUAN}

Pemanfaatan pengelolaan perikanan tangkap yang cenderung tanpa batas dan lebih berorientasi pada kepentingan ekonomi (economic bases fisheries resource management), telah berakibat buruk terhadap kelangsungan pemanfaatan sumber daya ikan. Dalam situasi pemanfaatan sumber daya ikan yang serba tak terkendali, kelangkaan (scarcity) atau penipisan sumber daya ikan. Kompleksitas dari kondisi yang demikian dapat memicu terjadinya konflik perikanan tangkap.

Pengelolaan sumber daya ikan pada hakekatnya adalah pengelolaan terhadap manusia yang memanfaatkan ikan tersebut. $\mathrm{Pe}$ ngelolaan terhadap manusia adalah pengaturan tingkah laku mereka dalam hal pengelolaan sumber daya. Priscoli (2002) menyatakan bahwa konflik sumber daya alam dapat disebabkan oleh miskinnya komunikasi, adanya perbedaan persepsi, pertarungan ego, perbedaan personalitas serta masalah stereo type, perbedaan pandangan tentang baik dan buruk (konflik nilai), perbedaan kepentingan dan faktor struktural. Konflik perikanan tangkap sangat bervariasi antar wilayah dan antar waktu. Bennett and Neiland (2000) menyatakan bahwa konflik bersifat multidimensional dan umumnya melibatkan berbagai pihak dalam hubungan yang kompleks. Tiga dimensi yang mempengaruhi timbulnya konflik adalah aktor, ketersediaan sumber daya dan dimensi lingkungan.

Pemerintah telah berupaya untuk mengatasi konfik perikanan tangkap yang muncul dengan mengeluarkan berbagai peraturan. Praktik pengelolaan konflik perikanan tangkap yang telah dilakukan di daerah penelitian (perairan Kalimantan Selatan) diharapkan efektif, pengelolaan konflik memberikan kontribusi yang signifikan terhadap perencanaan pengelolaan sumber daya, termasuk ke dalamnya sumber daya perikanan tangkap, karena tanpa pengelolaan yang tepat maka konflik dapat menghambat partisipasi masyarakat dan produktivitas nelayan. Penelitian ini bertujuan untuk menetukan model pengelolaan konflik perikanan tangkap berbasis resolusi konflik.

\section{METODE PENELITIAN}

\section{Lokasi dan waktu penelitian}

Lokasi penelitian dilaksanakan di desa pesisir Kalimantan Selatan yaitu wilayah yang merupakan basis terjadi konflik, yaitu: (1) Kabupaten Kotabaru (Desa Dirgahayu dan Desa Hilir Muara) dan (2) Kabupaten Tanah Laut (Desa Takisung, Tabanio dan Pagatan Besar) serta (3) Kabupaten Tanah Bumbu (Desa Wiritasi). Penelitian dilakukan sejak bulan JanuariApril 2009.

\section{Metode Penelitian}

Metode yang digunakan adalah metode survei. Data yang digunakan dalam penelitian ini bersumber dari data primer. Metode pengumpulan data dilakukan secara purposive terhadap 200 responden (mempertimbangkan jumlah covariam term, jumlah error variance dan path coeffisien dari model). Responden terdiri dari DKP, Lanal, Polair, anggota DPR, PPI, Kepala Desa, tokoh masyarakat, nelayan lokal yang terdiri dari pemilik kapal, ABK, pedagang penampung, nelayan andon, organisasi nelayan: POKMASWAS, INSAN, AMNES, HNSI, Lembaga Masyarakat: WALHI, serta akademisi. Informasi dikumpulkan dengan menggunakan kuisioner terstruktur.

\section{Variabel Penelitian}

Variabel penelitian terdiri dari tiga kelompok yaitu variabel faktor penyebab konflik, variabel resolusi konflik dan variabel outcome. Berdasarkan analisis tipologi konflik mengacu pada studi Bennet dan Neiland (2000) yang mencakup dimensi aktor, sumber daya dan lingkungan sebagai faktok penyebab konflik. Indikator resolusi konflik yang digunakan adalah: litigasi, negosiasi, fasilitasi, avoidance. Sedangkan variabel outcome yang diadopsi dari Losa et al. 2002; Barki and Hartwick (2001) serta Harris et al. (2000) terdiri dari tiga variabel yaitu: peningkatan partisipasi masyarakat dalam pengelolaan perikanan tangkap, pemahaman pengelolaan sumber daya perikanan tangkap yang berlanjutan, pengelolaan sumber daya perikanan tangkap yang berkeadilan. 


\section{Analisis Data}

Model pengelolaan konflik dilakukan dengan analisis struktural equation modeling (SEM). SEM merupakan pendekatan terintegrasi antara faktor, model struktural dan analisis path. Disisi lain SEM juga merupakan pendekatan yang terintegrasi antara analisis data dengan konstruksi konsep. Di dalam SEM peneliti dapat melakukan tiga kegiatan secara serentak, yaitu pemeriksaan, validitas dan reliabilitas instrumen (Wijanto 2007).

\section{HASIL DAN PEMBAHASAN}

Sebelum melakukan analisis untuk mengetahui sejauh mana kekuatan pengaruh antar konstruk dan pengukuran maka terlebih dahulu yang dilakukan adalah menilai Goodness Of Fit (GOF). GOF suatu SEM secara menyeluruh (overall) tidak dapat dilakukan secara langsung. SEM tidak mempunyai satu uji statistik terbaik yang dapat menjelaskan "kekuatan" prediksi model, sehingga dapat menggunakan ukuran GOF secara bersama-sama atau kombinasi.

Berdasarkan Tabel 1, uji kecocokan absolut menggunakan ukuran Chi-Square $\left(X^{2}\right)$, probability ( $p$ ), GFI (Goodness of Fit Index) dan RMSEA (Root Mean Square Error of Approx- imation) dengan nilai memenuhi syarat (cut off value) tidak terdapat pelanggaran nilai kritis, dengan demikian derajat prediksi model keseluruhan (model structural \& pengukuran) sesuai dengan data. Ukuran kecocokan inkre-mental menggunakan ukuran NNFI (Adjusted Goodness of Fit Index), CFI (Comparative Fit Index), AGFI (Adjusted Goodness of Fit Index) dan IFI (Incremental Fit Index). Nilai CFI dan NNFI berada sedikit di bawah standar yang direkomendasikan (marginal fit), namun jika dilakukan pembulatan dengan menambahkan (0,03 dan $0,01)$ diperoleh nilai NNFI dan CFI setara dengan 0,90 , sehingga sudah memenuhi dan tidak terdapat pelanggaran nilai kritis dan diberi keterangan dapat diterima, diperkuat dengan ukuran AGFI dan IFI dengan nilai sudah memenuhi ukuran kecocokan inkremental. Uji kecocokan parsimoni menggunakan ukuran Normed Chi Square $\left(X^{2} / d f\right)$ dengan nilai memenuhi kriteria bahwa model memiliki kehematan tinggi. Kriteria lain dalam melengkapi uji kecocokan model ditunjukan oleh nilai $\mathrm{CN}$ (Critical "N") yang menunjukkan ukuran sampel mencukupi untuk digunakan, sehingga dapat dikemukakan bahwa analisis descriptive statistic menunjukkan bahwa model dapat diterima dan memuaskan.

Tabel 1 Evaluasi terhadap tingkat kecocokan data dengan model

\begin{tabular}{lccl}
\hline \multicolumn{1}{c}{ Kriteria } & Cut off Value & Hasil Model & Keterangan \\
\hline Chi-Square $\left(x^{2}\right)$ & Diharapkan kecil & 129,37 & Baik \\
Probability $(p)$ & $\geq 0,05$ & 0,33 & Baik \\
$X^{2} / d f$ & $\leq 2,00$ & 1,051 & Baik \\
GFI & $\geq 0,90$ & 0,93 & Baik \\
AGFI & $\geq 0,90$ & 0,91 & Baik \\
CFI & $\geq 0,90$ & 0,89 & Dapat diterima \\
NNFI & $\geq 0,90$ & 0,87 & Dapat diterima \\
RMSEA & $\leq 0,08$ & 0,016 & Baik \\
PGFI & $\geq 0,60$ & 0,67 & Baik \\
IFI & $\geq 0,90$ & 0,91 & Baik \\
CN & $\geq 200$ & 234,68 & Baik
\end{tabular}

Sumber: Output analisis data penelitian menggunakan LISREL 8.30 
Tabel 2 Hubungan antar variabel pada model confirmatory factor konstruk unidimensional variabel konflik perikanan tangkap

\begin{tabular}{|c|c|c|c|c|c|}
\hline \multicolumn{3}{|c|}{ Model } & Koefisien Jalur & t-hitung & Keterangan \\
\hline $\mathrm{X} 1$ & & \multirow{11}{*}{ KONFLIK } & 0.29 & 2.98 & Signifikan \\
\hline $\mathrm{X} 2$ & & & 0.24 & 2.46 & Signifikan \\
\hline $\mathrm{X3}$ & & & 0.30 & 3.09 & Signifikan \\
\hline $\mathrm{X} 4$ & & & 0.02 & 0.19 & Tidak signifikan \\
\hline $\mathrm{X5}$ & & & -0.03 & -0.32 & Tidak signifikan \\
\hline X6 & & & 0.61 & 5.38 & Signifika \\
\hline $\mathrm{X} 7$ & & & 0.15 & 1.60 & Tidak signifikan \\
\hline$\overline{X 8}$ & & & -0.04 & -0.42 & Tidak signifikan \\
\hline $\mathrm{X9}$ & & & 0.09 & 0.93 & Tidak signifikan \\
\hline $\mathrm{X} 10$ & & & 0.14 & 1.39 & Tidak signifikan \\
\hline $\mathrm{X} 11$ & & & -0.23 & -2.27 & Signifikan \\
\hline$\overline{Y 1}$ & & \multirow{4}{*}{ RESOLUSI } & 0.35 & 2.92 & Signifikan \\
\hline$\overline{\mathrm{Y} 2}$ & & & 0.41 & 4.33 & Signifikan \\
\hline Y3 & & & 0.59 & 4.50 & Signifikan \\
\hline$\overline{Y 4}$ & & & -0.18 & -2.00 & Signifikan \\
\hline $\mathrm{Z1}$ & & \multirow{3}{*}{ OUTCAME } & 0.68 & 3.72 & Signifikan \\
\hline$\overline{Z 2}$ & & & 0.42 & 4.01 & Signifikan \\
\hline Z3 & & & 0.15 & 1.54 & Tidak signifikan \\
\hline KONFLIK & & RESOLUSI & 0.48 & 2.80 & Signifikan \\
\hline RESOLUSI & & OUTCAME & 0.59 & 2.85 & Signifikan \\
\hline
\end{tabular}

Sumber: Output analisis data penelitian menggunakan LISREL 8.30

Merujuk hasil analisis SEM (Tabel 2), secara simultan menunjukan hasil yang signifikan bahwa semakin baik kemampuan mengidentifikasi faktor penyebab konflik maka semakin baik pula kemampuan menentukan teknik resolusi konflik dan kemampuan menentukan teknik resolusi konflik yang tepat berpengaruh langsung terhadap peningkatan outcome, yaitu pengelolaan perikanan tangkap yang bertanggung jawab.

\section{Faktor Penyebab Konflik}

Secara parsial, berdasarkan 11 (sebelas) indikator yang diajukan terdapat 5 (lima) indikator penyebab konflik yang secara signifikan memberikan kontribusi terhadap faktor pe- nyebab konflik. Indikator tersebut yaitu: (i) kompetesi dalam pemanfaatan sumber daya (ii) keberadaan pihak yang bertolak belakang (iii) kondisi perekonomian masyarakat (iv) banyak sedikitnya pihak yang terlibat dan (v) latar belakang budaya dan adat. Sehingga faktor penyebab konflik yang harus diperhatikan adalah interaksi dari kelima indikator tersebut. Hal ini sejalan dengan Walter (2000) yang menandaskan bahwa konflik tidak hanya disebabkan oleh satu faktor tetapi merupakan kombinasi dan akumulasi dari berbagai faktor penyebab konflik. Selain itu diperkuat oleh penelitian Budiono (2005) yang menyatakan bahwa penyebab konflik dapat terdiri dari satu atau kombinasi dari beberapa indikator. 


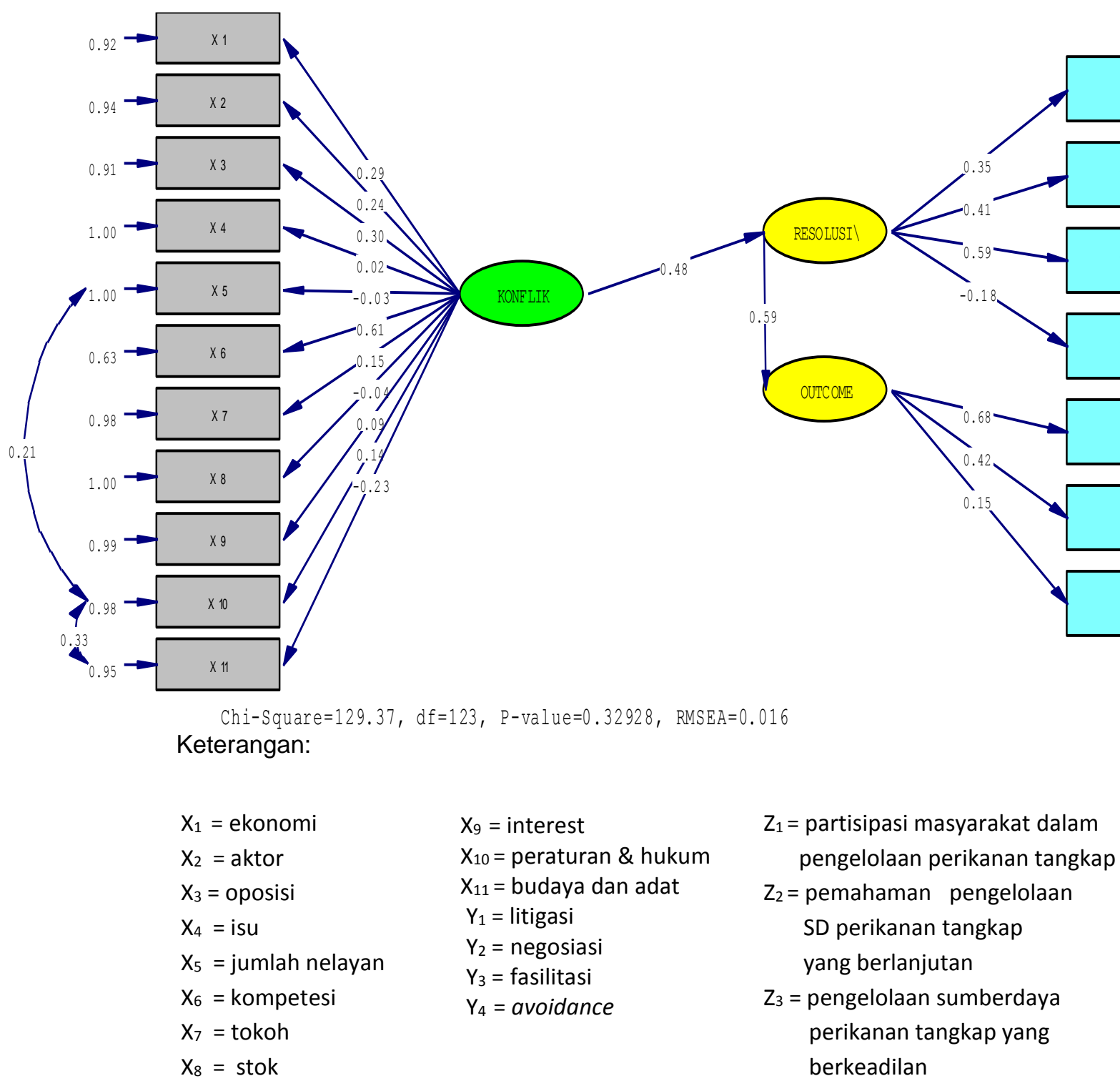

Gambar 1 Structural equation model yang menunjukan nilai estimasi.

\section{Faktor Penyebab}

Kompetisi merupakan indikator yang paling menentukan adanya konflik perikanan tangkap di perairan Kalimantan Selatan. Keberadaan alat penangkap ikan yang berbeda atau memiliki teknologi yang lebih tinggi cenderung dianggap menjadi pesaing bagi nelayan setempat. Seperti keberadaan nelayan purse seine yang menggunakan lampu, nelayan can-trang yang menyerupai teknologi trawl dan nelayan pemburu teripang menggunakan kom-pressor. Kehadiran alat tersebut sangat diyakini menjadi pesaing dan menguras sumber daya perairan. Hal ini sejalan dengan Dahuri et al. (1996) yang menyatakan konflik pemanfaatan timbul karena beberapa pengguna sumber daya berkompetisi untuk menggunakan sumber daya yang sama dalam ruang laut yang sama, dan menerapkan kegiatan-kegiatan yang memanfaatkan sumber daya tersebut yang tidak sesuai dengan yang lain. Dalam penelitian Lasut dan Kumurur (2001) juga menemukan bahwa kompetisi diantara pengguna untuk lahan atau fasilitas yang sama dapat menyebabkan konflik diantara pengguna. Menurut (Cincin-Sain and Knecht 1998) konflik umumnya terjadi karena beberapa sebab seperti kompetisi area, kompetisi sumber daya, atau kompetisi terhadap sumber daya yang saling berkaitan. Begitu pula dengan Warner (2000) mengidentifikasi empat hal yang dapat menjelaskan munculnya konflik atas sumber daya alam, diantaranya adalah kompetisi sumber daya alam (peningkatan 
ketergantungan pada sumber daya alam dapat meningkatkan persaingan).

Dalam penelitian ini keberadaan pihak yang bertolak belakang (oposisi) merupakan faktor kedua sebagai faktor penyebab konflik. Oposisi terjadi karena adanya kebijakan yang tidak sejalan sebagaimana terjadi pada kasus daerah tangkap yang mana kelompok nelayan yang tergabung ke dalam INSAN (Ikatan $\mathrm{Ne}$ layan Saijaan) tidak mendukung adanya pembagian daerah penangkapan). Hal ini sejalan dengan Bennet and Neiland (2000) mengemukakan bahwa aktifitas yang terkait dengan pengelolaan sumber daya wilayah pesisir yang berpotensi menyebabkan konflik selain kompetitif adalah antagonistik.

Selanjutnya hal penting yang diperhatikan dalam membangun resolusi konflik adalah masalah ekonomi nelayan. Perbedaan kondisi ekonomi nelayan di Kalsel dapat dilihat pada perbedaan usaha perikanan yang dilakukan yaitu mulai nelayan tradisional, semi dan modern serta adanya status punggawa dan ABK. Kondisi ini berpotensi untuk meningkatkan skala eksploitasi sumber daya kelautan dan perikanan yang berbeda dan menjadi lahan subur bagi timbulnya kerawanan-kerawanan di bidang kehidupan. Berdasarkan penelitian Torkrisna et al. 2002 bahwa pengalaman di Thailand, konflik terjadi antara nelayan kecil dan nelayan besar.

Banyak sedikitnya pihak yang terlibat merupakan faktor yang harus diperhatikan dalam resolusi konflik. Hal ini terkait dengan karakteristik individu dan kelompok. Semakin beragam karakter individu di dalam suatu wilayah semakin memicu konflik. Pada kasus konflik antar provinsi seperti kasus purse seine dan pengambilan teripang melibatkan banyak sekali pihak yang terlibat, selain nelayan yang bersangkutan termasuk lembaga yang menangani konflik baik pemerintah manupun non pemerintah mulai dari daerah hingga provinsi yang memiliki karekteristik beragam. Pemahaman terhadap aktor yang terkait dalam konflik menjadi sangat penting. Dalam kaitannya dengan hal tersebut Kaiser and Forsberg (2001) memberikan beberapa hal yang harus diperhatikan dalam pengelo-laan perikanan diantaranya jumlah stake holder perikanan.
Secara parsial latar belakang budaya dan adat berpengaruh secara negatif sebagai faktor penyebab konflik, dalam hal ini semakin berbeda latar budaya masyarakat justru dapat meredam konflik atau semakin kecil perbedaan latar budaya masyarakat di wilayah pesisir KalSel maka semakin besar kemungkinan terjadi konflik. Hal ini dapat dijadikan landasan kekuatan karena perbedaan budaya dalam masyarakat di pesisir Kalsel sudah menjadi bagian kehidupan masyarakat pantai. Kabupaten Tanah Bumbu berdasarkan sejarah sejak abad ke 17 suku bugis meminjam tanah dan mendirikan kerajaan Pagatan. Hingga sekarang daerah pesisir banyak etnis penduduk yang berasal dari Bugis, Mandar, Bajau dan sebagian lagi Bone, Jawa, Madura, Bali dan Thionghoa. Dengan terbangunnya pranata sosial masyarakat nelayan tersebut dan saling memahami budaya masing-masing, dapat dijadikan kekuatan kelembagan kearifan lokal masyarakat pesisir di Kalimantan Selatan dan diharapkan mampu menerapkan prinsip-prinsip penangkapan ikan yang bertanggung jawab.

\section{Teknik Resolusi Konflik}

Berdasarkan hasil analisis SEM, menunjukkan bahwa tenik fasilitasi memiliki koefisien loading tertinggi dibandingkan dengan negosiasi, litigasi dan avoidance. Penggunaan teknik ADR yaitu fasilitasi memiliki kontribusi terbesar dalam pembentukan variabel teknik resolusi konflik.

Pada kasus konflik daerah penangkapan paling sering menggunakan teknik litigasi. Setiap musim utara selalu saja ada bentrokan fisik akibat perebutan daerah penangkapan, kejadian berulang-ulang dan terjadi tindak kekerasan fisik, namun teknik litigasi yang digunakan ternyata justru memicu munculnya konflik ikutan dan mendorong timbulnya kemarahan antar kelomok. Kejadian tersebut sebenarnya sangat disayangkan karena aktor yang terlibat dalam konflik adalah sesama masyarakat nelayan lokal. Menurut Bennet and Nelland (2000) proses konflik yang menggunakan hukum formal (litigasi) akan menghasilkan suasana yang terisolasi, ada pihak yang dimenangkan dan dikalahkan.

Pada kasus konflik purse seine, resolusi dengan teknik litigasi dilakukan setelah adanya 
pembakaran kapal. Dalam hal ini litigasi hanyalah berupa tindak lanjut dari tindak kekerasan yang dilakukan. Sedangkan teknik litigasi pada kasus konflik pengambilan teripang dan kerang mutiara, teknik litigasi yang dilakukan kepada nelayan andon hanyalah merupakan proses yang bersifat memberikan efek jera karena tidak mengindahkan peringatan yang diberikan oleh nelayan Kabupaten Tanah Laut. Setelah nelayan berjanji untuk tidak melakukannya lagi pelaku segera di bebaskan. Jadi dalam kondisi ini litigasi hanya merupakan media politik untuk menyelesaikan sebuah konflik. Hal ini dianggap sebagai sesuatu keunggulan dari teknik litigasi dan sesuai dengan pendapat Gelanter (1996) yang menyatakan bahwa salah satu keunggulan dari teknik litigasi adalah bersifat politisi.

Konflik yang menggunakan teknik negosiasi yaitu konflik daerah penangkapan, pengambilan teripang dan kerang mutiara dan konflik purse seine. Negosiasi memberi peluang yang sangat luas bagi para pihak untuk menentukan pilihan-pilihannya. Dalam negosiasi, para pihak yang berkonflik tidak tergantung pada norma-norma hukum yang kaku dan tertulis dalam kitab-kitab undang-undang maupun dalam berbagai peraturan lainnya. Selain itu, negosiasi juga memberikan ruang bagi para pihak untuk bisa menang secara bersama-sama. Dalam negosiasi tidak ada yang kalah mutlak atau menang mutlak. Semua pihak memperoleh kesempatan untuk menjelaskan berbagai persoalan dalam proses negosiasi, dimana masyarakat nelayan bersatu sendiri menciptakan pemahaman bersama dan kemudian dikomunikasikan bersama kepala desa, pemimpin masyarakat lainnya terutama tokoh masyarakat dan masyarakat lokal lainnya. Semua aktor yang punya pemahaman yang sama dapat bernegosiasi dengan kelompok saingan, yang mengerti kesalahan mereka dan malakukan tawar menawar terhadap kesepakatan yang dapat diterima kedua belah pihak. Hal semacam ini memudahkan pendekatan resolusi konflik.

Namun teknik tersebut tampaknya masih terbatas pada membangun kesepakatan, hanya bersifat parsial, tidak tersosialisasikan dengan baik kepada pihak lainnya, pihak lain yang tidak mengetahui adanya kesepakatan tersebut ikut terseret sebagai aktor yang telah melanggar kesepakatan, sehingga konflik tidak berakhir tetapi justru berdampak pada tindak kekerasan dan anakis dengan melakukan pembakaran kapal. Negosiasi yang dilakukan pada waktu itu memiliki kelemahan, semestinya bisa dilakukan dengan melewati beberapa tahap. Sebagaimana yang telah dikemukakan oleh Priscoli (2002) yaitu: tahap pertama menunjuk kepada kondisi yang harus ada untuk semua pihak untuk masuk kepada ruang negosiasi tanpa kekerasan. Kondisi yang mendahului negosiasi mengidentifikasi bahwa: semua pihak yang terlibat konflik harus memahami bahwa di antara mereka terdapat perbedaan pandangan dan atau kepentingan, mereka harus memiliki kemauan untuk menyelesaikan konflik dengan opsi anti kekerasan, mereka harus punya kepentingan bersama (common interests) dalam kesepakatan dan memperoleh keuntungan bersama melalui saling memahami yang dituangkan dalam kesepakatan bersama itu. Jika satu sisi dapat menjatuhkan keputusan, sisi yang lain sebaiknya mengambil sikap agar isu itu tidak dimasukkan ke dalam suatu negosiasi. Kemudian pada tahap kedua, ketika suatu keputusan untuk negosiasi dilakukan, langkah selanjutnya adalah melakukan komunikasi berulang-ulang tentang bentuk inti dari negosiasi. Banyak faktor penentu dalam proses ini. Faktor-faktor tersebut termasuk beberapa pokok yaitu: komposisi tim negosiasi, persepsi pihak lawan berkaitan dengan pihak lainnya, sifat dasar dan saluran-saluran komunikasi, kepentingan relatif manusia versus isu, truktur negosiasi, gaya penawaran dan manfaat pihak ketiga.

Pada kasus lain, seperti konflik pengambilan teripang dan kerang mutiara teknik negosiasi yang digunakan justru memicu konflik yang lebih besar dan berdampak pada penyanderaan kapal. Hal ini dikarenakan hasil keputusan negosiasi belum disetujui oleh kedua belah pihak yang berkonflik dan mutu hasil negosiasi belum komprehensif dan belum tersosialisasi. Menurut Priscoli (2002), terdapat dua faktor yang menentukan mutu hasil negosiasi adalah (1) masukan menuju pengambilan keputusan (decision making) oleh kedua belah pihak; dan (2) format yang digunakan untuk membuat persetujuan (form of agreement). Pada faktor pertama, proses pengambilan keputusan adalah ciri dasar dari kegiatan negosiasi; proses ini haruslah dikelola secara hati- 
hati dan sensible dalam perjalanan negosiasi. Yang sering terjadi dalam pengambilan keputusan adalah bagaimana keputusan itu seharusnya dibuat daripada bagaimana keputusan itu dibuat. Para peserta dan alur negosiasi justru lebih peduli pada prosedur pengambilan keputusan daripada mengupayakan proses maju dalam modus partisipatif. Sedangkan pada faktor kedua, ketika sebuah kesepakatan dihasilkan, satu pertanyaan pen-ting adalah apakah kesepakatan tersebut berbentuk formal atau informal, karena kebanyakan kesepakatan dibuat secara formal dan tertulis. Dalam situasi tertentu, suatu kesepakatan tertulis mungkin ditambahkan melalui suatu kesepahaman informal. Dalam beberapa budaya, mekanisme pelaksanaan kesepakatan itu bersifat personal. Orang meletakkan komitmennya kepada manusia, bukan pada kontrak. Mereka memberi tekanan kepada hubungan antar manusia dan bukan pada kesepakatan-kesepakatan tertulis.

Konflik yang menggunakan teknik fasilitasi yaitu konflik daerah penangkapan, konflik bagan apung, konflik pengambilan teripang dan kerang mutiara, konflik seser modern, dan konflik purse seine. Jika dilihat dari frekwensi penggunaannya teknik fasilitasi adalah yang paling banyak digunakan, hal ini menunjukkan partisipasi pemerintah sangat besar dalam proses resolusi konflik di daerah penelitian. Hal ini sejalan dengan pendapat Cicin Sain and Knecht (1998) bahwa pengelola pesisir sering harus melakukan intervensi untuk menyelesaikan konflik. Hal ini penting untuk dipertimbangkan jika (a) konflik dapat mengancam keselamatan publik (b) konflik yang berlangsung dalam jangka panjang mengancam kelangsungan sumber daya bagi kemakmuran masyarakat atau terlibat pada kerusakan lingkungan yang tidak dapat pulih kembali (c) partisipasi dalam perselisihan tidak mewakili semua kepentingan yang terlibat atau (d) adanya inefisiensi dari pemerintahan.

Pada kasus konflik pengambilan teripang dan kerang mutiara pada awalnya dilakukan resolusi dengan teknik fasilitasi, namun karena perjanjian dan jalan keluar yang diambil bukan berasal dari kedua pihak yang berkonflik melainkan dari pihak luar (TNI AL), akibatnya kon- flik semakin meruncing akibat ketidakpuasan sebelah pihak. Kesepakatan diharap-kan dapat mencapai kondisi "kesepakatan yang berkesinambungan (durable settlement). Untuk dapat mencapai kondisi dengan durable settlement menurut Lincoln (1986) ada 3 (tiga) hal yang harus diperhatikan, yaitu: (1) substantive interest, yaitu: content need, dana, waktu, material dan sumber daya (2) prosedural interest, yaitu kebutuhan dan perilaku tertentu atau cara bagaimana sesuatu dapat diselesaikan (3) relationship or phsychological interest, yaitu kebutuhan yang merujuk pada perasaan seseorang, bagaimana seseorang diperlakukan dan prekondisi untuk menciptakan hubungan yang berkelanjutan.

Konflik purse seine dan konflik pengambilan teripang dan kerang mutiara termasuk kepada skala antar provinsi, sehingga sudah seharusnya untuk dilakukan dengan melibatkan pemerintah. Dalam hal ini fasilitator akan membantu menciptakan iklim untuk pemecahan masalah dan membantu membingkai masalah sehingga bisa dipecahkan. Fasilitator juga dapat menyarankan pilihan format atau prosedur untuk membantu kerja kelompok lebih efektif.

Namun penyelesaian dengan teknik fasilitas yang harus diperhatikan adalah keseimbangan kekuatan antara pihak yang berkonflik sebagaimana yang dinyatakan oleh Malik et all (2003) yaitu jika posisi para pihak tidak seimbang dan terserap pada pertemuan atau pun dialog-dialog penyelesaian konflik sumber daya alam, dapat dipastikan bahwa kesepakatan yang diambil akan mengundang sejumlah unsur ketidakadilan bagi komunitas-komunitas masyarakat setempat.

Konflik yang menggunakan teknik avoidance yaitu konflik daerah penangkapan, konflik gillnet dan konflik penggunaan bom. Resolusi konflik gillnet dan penggunaan bom dilakukan dengan teknik avoidance karena tidak bisa mempertemukan kedua belah atau pihak yang berkonflik dan tidak bisa berinteraksi. Hal ini disebabkan pelaku pengguna bom telah meninggalkan jejak atau melarikan diri sebelum sempat bertemu muka. Kasus tersebut sebenarnya merupakan tindakan illegal fishing dan 


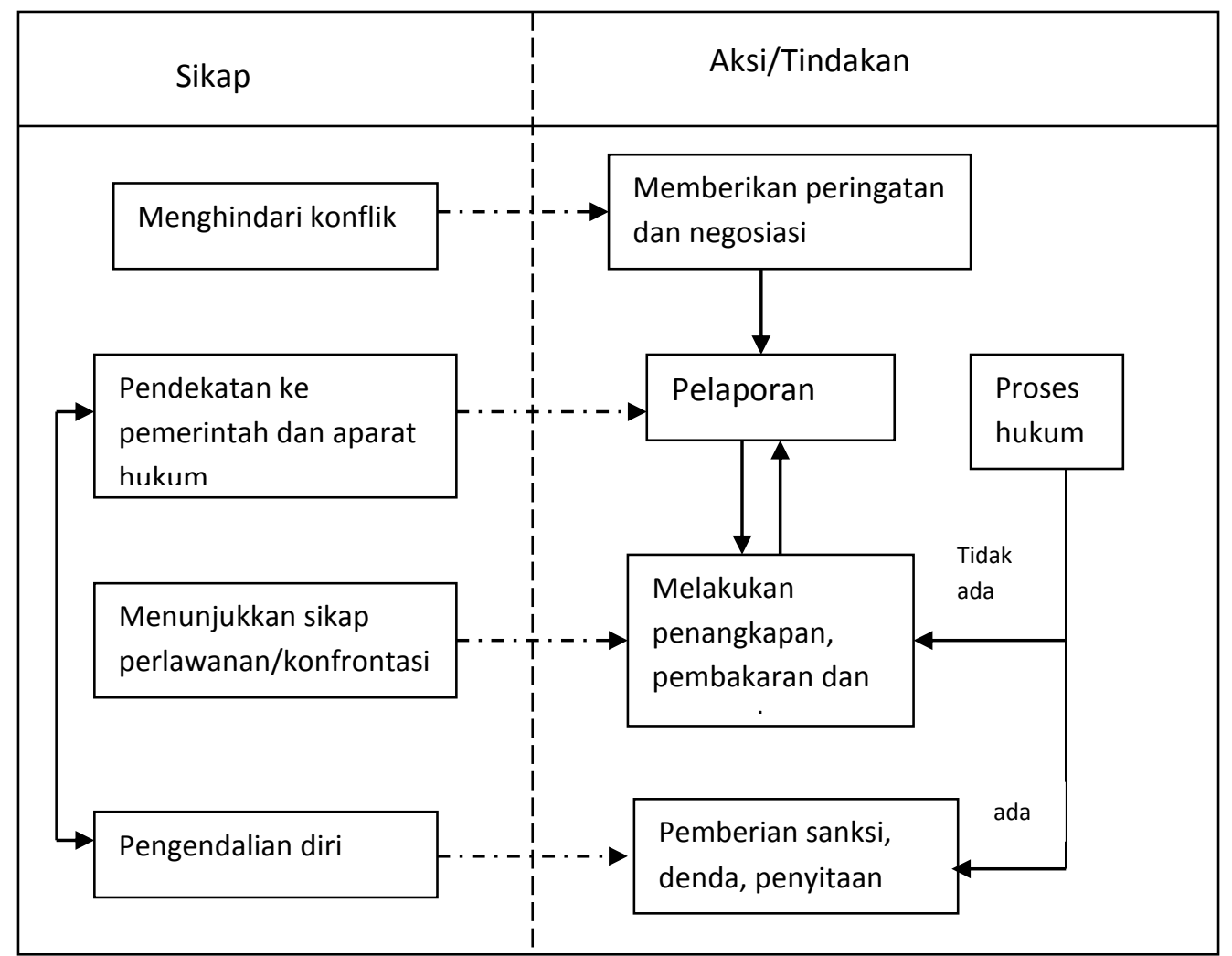

Gambar 2 Mekanisme penanganan konflik perikanan tangkap di perairan Kalimantan Selatan.

sudah ada ketentuan pidana hukum bagi penggunanya, seharusnya dilakukan dengan teknik litigasi yaitu dapat diproses secara hukum, namun konflik tersebut dapat berakhir dengan cara avoidance. Hal ini menunjukkan bahwa telah terjadinya kesadaran hukum terhadap prekondisi atau peraturan pemerintah yang telah diberlakukan dan efektifnya pengawasan yang dilakukan baik oleh pokmaswas maupun oleh aparat pemerintah.

Secara umum mekanisme penanganan konflik yang dilakukan mulai dari memberi peringatan sampai pada aksi perlawanan atau konfrontasi yang berujung pada tinndakan kekerasan dan pembakaran dapat dilihat pada gambar 2 .

Seiring makin banyaknya konflik yang tidak mampu tertampung dan tidak terselesaikan oleh lembaga peradilan, banyak pihak terdorong mencari lembaga alternatif untuk menyelesaikan konflik. Jika mekanisme penyelesaian konflik yang dipilih untuk digunakan itu tidak melanggar rambu-rambu hukum seperti pada kasus penggunaan seser modern dan konflik bagan apung. Mekanisme yang dipilih disepakati oleh para pihak yang berkonflik, karena kesepakatan tersebutlah yang meletakkan landasan bahwa cara penyelesaian yang dipilih itu menjadi hukum bagi para pihak yang berkonflik. Hal ini sejalan dengan Koesno (1979) yang mengatakan bahwa karakteristik masyarakat Indonesia yang lebih mengutamakan kerukunan dan kerjasama, merupakan prasyarat penting bagi suksesnya penggunaan teknik ADR.

Resolusi konflik dapat digunakan sebagai dasar pengelolaan yang mengakomo-dasi perbedaan kepentingan semua pihak. Sebagaimana yang dinyatakan Al-Tabbai (1991) dalam penelitiannya bahwa resolusi konflik pada dasarnya adalah menutup kesenjangan kognitif diantara pihak yang berkonflik. Dalam penelitian Hill (1992) menyatakan bahwa kedua belah pihak yang berkonflik memperoleh kemenangan (win-win solution) sebab resolusi konflik harus dapat diterima oleh kedua belah pihak.

Dampak dari aplikasi teknik resolusi konflik yang tepat diharapkan dapat memberikan pengaruh terhadap pengelolaan sumber daya perikanan tangkap yang berkelanjutan. Agar pengelolaan sumber daya perikanan di Kalimantan Selatan dapat tercipta, pemerintah 
harus membangun suatu kondisi stakholders dengan mempertimbangkan partisipasi masyarakat tentang pengelolaan sunberdaya perikanan tangkap dan pemahaman masyarakat tentang pengelolaan sumber daya perikanan tangkap yang berkelanjutan. Peran pemerintah tersebut dapat dilakukan diantaranya melalui penciptaan iklim yang memungkinkan masyarakat nelayan untuk mengemukakan ide dan keinginannya. Masyarakat nelayan juga harus diberikan peluang untuk membentuk organisasi pengelolaan sumber daya perikanan sesuai dengan keinginan serta membangun kerja sama.

Berkaitan dengan upaya meningkatkan peranserta masyarakat dalam resolusi konflik, merujuk pada pengalaman Jepang, Thailand, Philipina dan beberapa negara lain dalam pengelolaan sumber daya perikanan, ternyata partisipasi masyarakat memberikan kontribusi yang signifikan dalam mewujudkann kelestarian sumber daya ikan (Hanna 1980). Pada umumnya negara tersebut menggunakan model pengelolaan sumber daya perikanan berbasis komunitas dan menghormati nilai budaya masyarakat.

\section{KESIMPULAN}

Dalam model optimal pengelolaan sumber daya perikanan tangkap berbasis resolusi konflik (i) Secara simultan ditemukan bahwa semakin baik kemampuan mengidentifikasi faktor penyebab konflik maka semakin baik pula kemampuan menentukan teknik resolusi konflik. Selanjutnya semakin baik kemampuan menentukan teknik resolusi konflik yang tepat maka akan meningkatkan dukungan terhadap pengelolaan sumber daya perikanan tangkap yang bertanggung jawab; (ii) Secara parsial faktor penyebab konflik ditentukan oleh indikator kompetisi, oposisi, ekonomi, aktor dan budaya; (iii) Secara parsial teknik fasilitasi, negosiasi, litigasi dan avoidance dapat digunakan sebagai teknik resolusi konflik yang tepat (iv) Secara parsial pemahaman terhadap partisipasi masyarakat, pemahaman terhadap pelestarian sumber daya perikanan tangkap berkelanjutan menentukan terciptanya pengelolaan sumber daya perikanan tangkap yang bertanggung jawab.

\section{DAFTAR PUSTAKA}

Al-Thabbai, Alex P, Alex, \& Alfatoosh AA. 1991. Conflict Resolutions Using Cognitive Analysis Approach. Project Management Jornal. No. 54:68-87.

Aubert V. 1963. Competition and dissensus: two type of conflict and conflict resolution. Conflict Resolution Journal. No. 7:26-42.

Barki H., Hartwick J. 2001. Interpersonal Conflict And Its Management In Information System Development. McGill University Montreal, Quebec, Canada. p. 65.

Bennett E., Neiland A. 2000. Review of Study Approach to Conflicts. Centre for the Economics and Management of Aquatic Recources (CEMARE). p.122

Budiono A. 2005. Keefektifan Pengelolaan Konflik Pada Perikanan Tangkap di Perairan Selatan Jawa Timur [Disertasi]. Bogor: Program Pascasarjana, Institut Pertanian Bogor.

Cicin-Sain B, Knecht RW. 1998. Integrated Coastal and Ocean Management Concepts and Practices. Center for the Study of Marine Policy Graduate College of Marine Studies. University of Delaware. Island Press, Washington D.C. p. 517.

Dahuri R. 1996. Penyusunan Konsep Pengelolaan Sumber daya Pesisir dan Lautan yang Berakar di Masyarakat. Kerjasama Ditjen Bangda dengan pusat Kajian Sumber daya Pesisir dan Lautan. IPB.

Gelanter M. 1966. Hukum Hindu dan Pengembangan Sistem Hukum India Modern. Sinar Harapan. Jakarta. p. 32.

Hanna, Susan. 1998. Co-Management in Small-Scale Fisheries: Creating Effective Link Among Stakeholders. International CBNRM Workshop. Washington. p. 213.

Harris, Peter, \& Reilley B. 2000. Demokrasi dan konflik Mengakar: Sejumlah Pilihan untuk Negosiator. IDEA. p. 12.

Hair JF, Anderson RE, Tatham RL \& Black WC. 1998. Multivariate Data Analysis. Fifth Edition. Prentice Hall-International. INC. 
Prited in the United States of America. p. 79.

Hill B. 1982. An Analysis of Conflict Resolution Techniques: From Priblem Solving Workshops to Theory. Conflict Resolution Journal. No. 26: 109-138

Koesno M. 1979. Catatan-catatan terhadap hukum adat Dewasa ini. Surabaya. Airlangga University Press. p. 45.

Kaiser, Forsberg EM. 2001. Assessing Fisheries Using an Ethical Matrix ini a Participatory Process. J Agricultural and Environmental Ethics 14:191-2000.

Lasut MT dan Kumurur VA. 2001. Konsensus Tekanan Antropogenik pada Wilayah Pesisir: Konflik kepentingan. Jurnal Ikoton. No. I: 71-77.

Lincoln WF. 1986. The Course in Collaborative Negotiation. Tacome. Wash. Nasional Center Assoociattes, Inc.

Losa FB, Houbert RV, Joubert A. 2002. The Multivariate Analysis Biplot as a Tool for Conflict Analysis. Multicriteria Decision Analysis Journal. No. 10: 273-284.

Malik I, Fauzi N, Wijardjo B, \& Royo AG. 2003. Menyeimbangkan Kekuatan Pilihan Stra- tegi Penyelesaian Konflik atas Sumber Daya Alam (Ed. Pellokila YK, Prasetyohadi, Trisasongko D). Gramedia. Jakarta. p. 539.

Tokrisna, Ruangrai, Boonchuwong P, Janekarnkij P. 2002. A Review on Fisheries and Coastal Community based CoManagement Regime in Thailand. Procedings of the International workshop on Fisheries Co-Management. p. 65.

Priscoli JD. 2002. Participation, Consensus Building and Conflict Management Training Course. UNESCO-IHP. p. 187.

Warner M. 2000. Consensus participation: an example for protected area planning. $\mathrm{Pu}$ blic Administration and Development Journal. No. 17:413-432.

Walter CJ and Hillborn R. 2000. Adaptive control of fishing system. The fisheries research board of Canada. System Journal. No. 22:145-159

Wijanto SH. 2007. Structural Equation Modeling dengan Lisrel 8.8. Konsep dan Tutorial. Graha Ilmu. Yogyakarta. p. 473. 